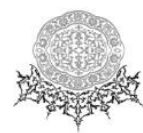

\title{
A Legitimate Response of Muslims towards Islamophobia
}

\author{
Muhammad Yaseen Naseem \\ Middle East Institute, \\ University of Sakarya, Turkey \\ Samraiz Hafeez \\ University of Central Punjab, \\ Lahore, Pakistan
}

\begin{abstract}
The Organization of Islamic Cooperation is a vocal inter-governmental organization of Muslim member states. It sets its own policy agenda and it established an Islamophobia Observatory in 2007 in its Directorate of Cultural, Social, and Family Affairs. The observatory works in the constituency of Cultural Affairs Department. It monitors and publishes the magnitude and state of Islamophobia observed across the world. Since 2007, it has published several observatory reports, monthly bulletins, and research articles in OIC journals on key incidents of discrimination, hate crimes, and stigmatization of Muslims as intolerant, radicals, violent, and terrorists across the world, particularly in the three continents of Europe, North America, and Australia. This research paper is based on the content analysis of the annual reports of Islamophobia Observatory, which has been exercised independently to observe the role of OIC to address Islamophobia as a legitimate response of the Muslim world. This study highlights the fact that Islamophobia Observatory has presented its every observatory report to the Islamic Conference of Foreign Ministers (ICFM) of OIC member states, which has responded to the issue at various levels. OIC is also addressing this issue at global level. Therefore, OIC has been successful in making Islamophobia a part of international discourse of human rights. Now, it is known as a social evil and its stakeholders have started mitigating it through proper institutional coordination at all levels.
\end{abstract}

Keywords: Islamophobia, Organization of Islamic Cooperation, Islamophobia observatory, International commitments, legitimate response

\section{Islamophobia}

United Nations (UN) defined Islamophobia in its special report of UN Human Rights Council on Contemporary Forms of Racism, Radical Discrimination and Xenophobia in 2007 as 'a baseless hostility and fear vis-à-vis Islam and, as a result, a fear of, and aversion towards all Muslims or a majority of them.' Like other 


\section{상}

kinds of phobia, Islamophobia is not possessed by individuals only; rather it is possessed by a large section of the host population. ${ }^{1}$

In fact, it is not a new phenomenon. It emerged a few decades ago at the end of Cold War in Eastern Europe, Caucasus and to some extent in Central Asian region as an antagonistic force to prevent Muslims to preserve and promote their Islamic identity and to express their right of self-determination. Resultantly, every newly liberated state from Union of Soviet Socialist Republics had to face severe bloodshed, multilateral waves of ethnic cleansing and hate crimes towards Muslims. Later, some so-called scholars and orientalists presented and propagated their false premise as a clash of civilizations. Consequently, they unilaterally demonized Muslims and Islam as the future enemy of Western civilization. Samuel P. Huntington wrote, that Western civilization will face Islam as a constant threat in future rather than the temporary threat from Islamic fundamentalism. Similarly, Vincent Geisser said that Islamophobia is not a manifestation of historical rivalry since Crusade, rather it is pure 'anti-Muslim racism.'

Historically, the term Islamophobia appeared for the first time in an official report of Runnymede Trust in 1997, which coded the discriminatory attitude of White Anglo-Saxon Protestants of British with their Muslim fellow citizens. It must be noted that it did not discover the phenomenon, but gave it a name which gained currency rapidly. ${ }^{3}$ Currently, it is associated with a known vocabulary of offensive, hurting, discriminating, hateful, inciting, stereotyping, provocative, insulting, defaming, and denigrating expressions of Muslims and Islam. ${ }^{4}$

According to the observations of Islamophobia Observatory of $\mathrm{OIC},{ }^{5}$ Islamophobia has four major expressions, Violence (physical assault, verbal abuse,

\footnotetext{
${ }^{1}$ Islamophobia Observatory, " 8 th OIC Observatory Report on Islamophobia" (Kuwait: Organization of Islamic Cooperation, 2015), 1-71, https://www.oicoci.org/upload/islamophobia/2015/en/reports/8th_Ob_Rep_Islamophobia_Final.pdf

${ }^{2}$ Islamophobia Observatory, "1st OIC Observatory Report on Islamophobia" (May 2007 to May 2008) (Kampala: Organization of Islamic Conference, 2008), 1-56.

${ }^{3}$ Dr. Anis Ahmed, "Editorial: Future of Islamophobia." Edited by Prof. Dr. Anees Ahmed. Maghrib aur Islam (West and Islam): Fear of Islam in the West 18 (43), 2 (IPS Press: Institute of Policy Studies, 2015), 5-13.

${ }^{4}$ M. Ronald, Ada P. Kahn, and Christine Adamec, The Encyclopedia of Phobias, Fears, and Anxieties (New York: Facts on File. 2008)

${ }^{5}$ Organization of Islamic Conference (OIC) was formulated in September 25, 1969 to protect collective interest of Muslim Ummah. Later, in $38^{\text {th }}$ conference (2011) of ICFM of OIC member states at Republic of Kazakhstan, the logo and official name of the organization was amended and fixed as Organization of Islamic Cooperation (OIC). It is one of the world's second largest intergovernmental organization, which has 57 Muslim majority member states. It focuses on international peace, security and harmony. Its charter shares its aims as; to recognize the right of self-determination, territorial integrity; to give input and participate at global intergovernmental forums to assist for formulation of inclusive global policies and to take decisions through respecting UN Charter and international laws;
} 


\section{상}

vandalizing of property), Prejudice (in the mass media and social media and other kinds of conversations), Discrimination (at work place and departments of social services) and Exclusion (from employment, politics and government, and from other spheres of national life). ${ }^{6}$

\section{Realization of Islamophobia by OIC}

OIC realized the threat of Islamophobia and passed recommendations to take initiative to address the issue at institutional level. Later, it conducted its $3^{\text {rd }}$ Extraordinary Islamic Summit at Mecca and adopted its Ten-Years Program of Action in 2005. Here, it was decided to take measures to mitigate the issue. ${ }^{7}$ It also formed Islamophobia Observatory to estimate the magnitude of Islamophobia all over the world. OIC took another initiative to establish a technical body to detect and block the blasphemous and Islamophobic content on the Internet. It is called Computer Emergency Response Team (CERT). It was established by the resolution passed in the ICFM of OIC in 2009. ${ }^{8}$

While addressing the $42^{\text {nd }}$ Islamic Conference of Foreign Ministers (ICFM) of OIC member states, he described Islamophobia as,

it is a regrettable fact that manifestations and incidents of hostile, defamatory, discriminatory, xenophobic and racist discourse and actions against Muslims especially in the West is still on the increase in their scope and intensity...Islamophobia is also manifested through intolerance, discrimination and adverse political, media and even academic public discourse...Islamophobia is mainly based on radicalization and demonization of a religion and its followers. As such, Islamophobia is a direct and clear assault on the human rights and dignity of Muslims. ${ }^{9}$

In his special message to the Journal of OIC, he expressed his concern that Islamophobia was one of the biggest security threats to the world, which carried a momentous magnitude to prematurely hurt, discriminate and defame Muslims and Islam. He mentioned that violent acts of individuals were being projected as a manifestation of collective response of all Muslims in the world, who firmly believed

to promote Islamic model of economics; to work for Palestine cause; to take stand against defamation of religion particularly for Islam through dialogues and debates etc. Organization of Islamic Cooperation, History of Organization of Islamic Cooperation. Accessed March 12, 2016. http://www.oic-oci.org/oicv3/page/?p_id=52\&p_ref=26\&lan=en.

${ }^{6}$ Islamophobia Observatory, "7 ${ }^{\text {th }}$ OIC Observatory Report on Islamophobia" (Jeddah:

Organization of Islamic Cooperation, 2014), 1-120, https://www.oic-

oci.org/upload/islamophobia/2014/en/reports/islamophoba_7th_report_2014.pdf

${ }^{7}$ Islamophobia Observatory, "1 ${ }^{\text {st }}$ OIC Observatory Report on Islamophobia" (May 2007 to

May 2008) (Kampala: Organization of Islamic Conference, 2008), 1-56, http://ww1.oic-

oci.org/uploads/file/Islamphobia/islamphobia_rep_may_07_08.pdf

${ }^{8}$ Mohamed Elbusefi, "Tackling Blasphamous E-Content against Islam," OIC Journal

(Organization of Islamic Conference) no 12 (2009): 54.

${ }^{9}$ Islamophobia Observatory, " $8{ }^{\text {th }}$ OIC Observatory Report on Islamophobia," 1-71, https://www.oic-oci.org/upload/islamophobia/2015/en/reports/8th_Ob_Rep_Islamophobia_Final.pdf 


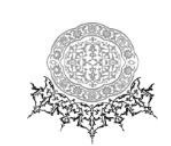

in universal and comprehensive message and principles of Islam, such as respect, tolerance, freedom and peace for all. So, a universal community of Muslims cannot be associated with extremism and terrorism at all. He said that the undefined boundaries of freedom of expression had violated the basic human rights through making caricatures of sacred personalities. It had offended the faith of Muslims and previously defined code of ethics of journalism.

He mentioned that Western school of thought and orientalists should revisit their petite understanding of Islam, since they have built their perceptions about Muslims and Islam on very weak foundations. He assured that OIC will play its key role as a legitimate source for peace and harmony to draw down the magnitude of this "unholy campaign" of ill minded people against Muslims and Islam. He highlighted that OIC had taken up this issue as its policy agenda to spread awareness about Islamophobia at UN and other effective forums in the world. He further highlighted that he personally had made this issue a part of his speeches and points of negotiations at $62^{\text {th }}$ session of General Assembly of United Nations, other intergovernmental forums including leading think thanks of US, West and rest of the world. In his visit to USA, he visited and spoke in academic and professional research institutions ${ }^{10}$ about the role of media to bridge the gap between East and West. He shared his views about Islamophobia and the role of media in launching and promoting it.

He emphasized that this phenomenon had existed before the incident of $9 / 11$, but a sensational increase had been observed after the incident, which indiscriminately and abruptly demonized a known peaceful majority of Muslims as perpetrators of it. As a result, international media followed the same discourse and started a global campaign against Muslims and Islam. Therefore, this was the right time to realize the fact that we were fighting against either innocents or with the culprits. ${ }^{11}$ In his address to the ICFM of OIC, he mentioned that OIC had convinced the UN and its relevant agencies to play their key role to eradicate Islamophobia through international understanding (passing resolutions and organizing conventions) and legislation. He mentioned that we must not forget our role to address this issue at all levels and at all forums, which we frequently or rarely visited. ${ }^{12}$

He addressed the $6^{\text {th }}$ Islamic Conference of Culture Ministers and reinforced his commitment to harness all available resources to counter the phenomenon of

\footnotetext{
${ }^{10}$ International Peace Academy, Carnegie Council, Council on Foreign Relations, Princeton University, and Georgetown University.

${ }^{11}$ Prof. Ekmeledin Ihsanoğlu, "Ihsanoğlu lectures on the Role of Media in East and West Relations," OIC Journal (Organization of Islamic Conference). no. 5, (2007):11.

${ }^{12}$ Prof. Ekmeledin Ihsanoğlu, "At the Annual Coordination Meeting of OIC Foreign Ministers: Ihsanoglu Presents Achievements and Objectives," OIC Journal (Organization of Islamic Conference). no. 12, (2009):16.
} 


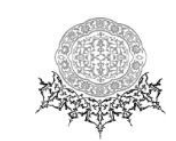

Islamophobia. ${ }^{13}$ In his address at Lisbon, he stated that OIC is amongst the biggest forums in the world, which organized interfaith and inter-cultural dialogues. ${ }^{14}$ General Secretory, Ambassadorial Group to Geneva of OIC and UN Commission for Human Rights (upon the report of OIC) condemned the political campaign of Swiss People's Party to ban Scarf and Minaret of mosques of Muslims in Switzerland. OIC convinced the target institutions to declare this development as an attack on fundamental human rights and freedom of practicing religion. ${ }^{15}$

He further noted that Muslims living in North America and Western Europe were facing identity crisis. There is no doubt that mass media, biased scholarship and unstructured sense of historical rivalry had made the public in them narrow minded towards Muslims. He mentioned that Islamophobia cannot be prematurely generalized in the West and America at all, because there was an institutional process and sincere or human-rights loving people who took stand against such subversive propaganda, but the momentum of their good manifestation remains inferior to the magnitude of Islamophobia. ${ }^{16}$

It must be noted that Mass Media is not only the launching pad of Islamophobia, but Social Media is the most effective tool of this phenomenon, which is very hard to monitor and block, as governments of UAE, Pakistan and Indonesia blocked Youtube.com in protest against the presence of blasphemous videos, but the problem and significance of the crisis was not realized by the West and America and they failed to respect Islam and preserve the basic human rights of Muslims. ${ }^{17}$

In $37^{\text {th }}$ session of ICFM, the participants observed that the reporting of cases of Islamophobia all over the world. They were astonished by the fact that local governments are ineffective to solve their social issues for certain communities. They reinforced their commitment to do more in this regard. ${ }^{18}$ The Secretary General of OIC shared his observations with the same participants that the right wing political parties in Europe are the real cause of Islamophobia. He mentioned that he

\footnotetext{
${ }^{13}$ Prof. Ekmeledin Ihsanoğlu, " 6 th $I$ Islamic Conference of Culture Ministers Adopt Action Plan for Joint Islamic Cultural Action,” OIC Journal (Organization of Islamic Conference). no. 12, (2009): 40.

${ }^{14}$ Prof. Ekmeledin Ihsanoğlu, "Lisbon Forum 2009: OIC Secratory General Stresses on Need to Catalyze Intercivilizational and Interfaith Dialogue," OIC Journal (Organization of Islamic Conference). no. 12, (2009): 42.

${ }^{15}$ Prof. Ekmeledin Ihsanoğlu, "Stopp Jazum Minarett-Verbot," OIC Journal (Organization of Islamic Conference). no.12, (2009): 44.

${ }^{16}$ Ambassador (R) Ömür Orhun, "Muslims in the West," OIC Journal (Organization of Islamic Conference) no. 12, (2009): 46-47.

${ }^{17}$ Mohamed Elbusefi, “Tackling Blasphamous E-Content against Islam," OIC Journal (Organization of Islamic Conference). no. 12 (2009): 54.

${ }^{18}$ Dr. Isam Salim Shanti, "Dushanbe Meeting: Realities and Changes," OIC Journal (Organization of Islamic Conference). no.13, (2010): 6.
} 


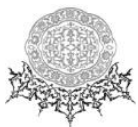

had engaged ministers for foreign affairs of various European countries (Holland, Germany, Finland, United Kingdom, France, Denmark, Switzerland and Spain) to address the issue effectively. ${ }^{19}$

According to the report of 'Council of American-Islamic Relations,' Islamophobia and ideological violence against Muslims is not only manifested by the religious community, but it is also harnessed by well-educated secular and liberal social segments of host society for their purposes. Even law enforcement agencies are not far behind in this social crime. ${ }^{20}$ The advisor to the Secretary General of OIC presented his views that Muslim world is at a historical juncture, where economic failure, bad governance, foreign occupation, leadership crisis and Islamophobia are at their peak to disturb its social order with their collective force. ${ }^{21}$ Therefore, OIC is convinced that contemporary international political, diplomatic and mass media narrative is composed of subversive nomenclature against Muslims and Islam (such as Islamic terrorism; Islamic fundamentalism; Islamic extremism; Islamic fascism etc.), which has directed the attention of international community from shared goals of global peace, harmony and human development to the baseless propaganda which isagainst a multicultural majority population of Muslims. ${ }^{22}$

\section{Islamophobia Observatory of OIC}

General Secretory of OIC addressed the $33^{\text {rd }}$ session of ICFM of OIC member states, where he stated that OIC has convinced European Union (EU) and United Nations (UN) to issue a joint statement for international mass media to follow moral values to stop spreading hatred against religious beliefs of others particularly of Muslims. He discussed a successful plan to establish an Islamophobia Observatory in the General Secretariat of OIC (Jeddah) to both monitor and document all of the identified activities against Muslims and Islam. He further added that the were seriously observing this issue since many years and have taken onboard United Nations' Commission for Human Rights, General Assembly of United Nations, and United Nations Educational, Scientific and Cultural Organization

\footnotetext{
19“'Ihsanoglu suggests evolving an Islamic plan for interaction with the West on Islamophobia," OIC Journal (Organization of Islamic Conference). no. 14 (2010):17.

${ }^{20}$ Nihad Awad, "Anti-Muslim Bias on the Rise in the US," The Journal (Organization of Islamic Conference). no. 5 (2007): 22.

${ }^{21}$ Ambassador Saadeddin Taib, "What Does the OIC Stand for?" The Journal (Organization of Islamic Conference). no. 5 (2007): 40.

${ }^{22}$ Isam Salim, edited, "Islamophobia: Looking at the Causes and and Ways to tackle Them," The Journal. Organization of Islamic Cooperation, (2006), Accessed April 10, 2016. http://www.oicoci.org/english/article/islamophobia.htm.
} 


\section{상}

(UNESCO) to realize Islamophobia as an international crisis of defamation of religion, where Islam and Muslims are deadly victims of it. ${ }^{23}$

Then, a decision was taken in $34^{\text {th }}$ Islamic Conference of Foreign Ministers and $11^{\text {th }}$ OIC Summit held at Islamabad (2007) and Dakar (2008) respectively to prepare a comprehensive report on Islamophobia about host populations in the world. ${ }^{24}$ Later, Islamophobia Observatory was established (2007) under the constituency of Directorate of Cultural, Social and Family Affairs Departments ${ }^{25}$ of OIC. Since its inception, Islamophobia Observatory monitors the trends and sites of Islamophobia in host societies, prepares annual reports and monthly bulletins of Islamophobia, and gives updates to the other relevant organs of OIC on the state of Islamophobia. ${ }^{26}$

\section{Observations of Islamophobia Observatory}

Islamophobia Observatory publishes monthly bulletins and annual reports since 2008. These annual reports are written on the basis of observations taken from monthly bulletins, which are made conversant of all observed cases of Islamophobia all over the world. This study is limited to organize a content analysis of the annual reports of Islamophobia Observatory only, which is comprehensively conversant of actors and reasons of Islamophobia in certain parts of the world and how OIC has played its role to develop a legitimate voice of Muslim world to mitigate the phenomenon.

\section{Actors of Islamophobia}

The phenomenon of Islamophobia can be observed in almost every nonMuslim country, but Europe, North America and Australia are leading in this regard, where leftists and rightists both possess it. These individuals and groups (including organizations) belong to various walks of life in those countries. Therefore, the following information contains high profile cases and incidents of Islamophobia as

\footnotetext{
${ }^{23}$ Prof. Ekmeledin Ihsanoğlu, Speech of His Excellency Prof. Ekmeledin Ihsanoğlu Secratory General of the Organization of the Islamic Conference, Accessed April 16, 2016. http://www.oicoci.org/baku2006/english/sg-speech.htm.

${ }^{24}$ Islamophobia Observatory, “ $1{ }^{\text {st }}$ OIC Observatory Report on Islamophobia (May 2007 to May 2008),” (Kampala: Organization of Islamic Conference, 2008), 1-56, http://ww1.oicoci.org/uploads/file/Islamphobia/islamphobia_rep_may_07_08.pdf

${ }^{25}$ This Directorate is divided into two Departments named Social and Family Affairs Department, and Cultural Affairs Department. It is responsible for dealing of cultural affairs of Muslim communities in all over the world. It studies and conducts intercultural and interfaith dialogue as it has organized United Nations Alliance of Civilizations. It tries to tackle the challenges of Islamophobia; protection and preservation of Islamic Sites, particularly an Islamic character of alQuds.

${ }^{26}$ Dr. Isam Salim Shanti, (editor), "Islamophobia: Looking at the Causes and and Ways to tackle Them," The OIC Journal (2006) Accessed April 10, 2016. http://www.oicoci.org/english/article/islamophobia.htm.
} 


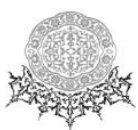

those were mentioned in the annual reports of Islamophobia Observatory since 20082016.

\subsection{Observations from May 2007 to May 2008}

- Third official report of "European Commission against Racism and Intolerance" (2007) described that The Netherlands had led the European countries in its special trends of Islamophobia.

- A Dutch Parliamentarian released a film titled Fitna, which had highly blasphemous content.

- Seventeen Danish newspapers published blasphemous content about Qur'ān and cartoons of Prophet Muhammad $(S A W) .{ }^{27}$

- World Economic Forum reported (2008) that Europeans felt threatened by interaction with Muslims with a certain ratio, such as Denmark (79\%), Spain (68\%), Netherland and Italy (67\%), Sweden (65\%), Belgium (59\%).

- Member of Parliament of far-right political party titled Freedom Party in the Netherlands named Geert Wilders demanded for banning Holy Qur'ān, mosque and immigration of Muslims in the country.

- Danish People's Party used a caricature of Prophet Muhammad ( $S A W)$ in its election campaign.

- A candidate of Freedom Party of Austria abused the family of Prophet Muhammad (SAW) and Islam.

- An Italian coordinator of Northern League organized a march titled 'Pig Day against new Mosques.'

- 'Swiss People's Party' (the largest party at Swiss Parliament) launched a campaign for banning the minarets of mosques and did propaganda that Muslims are tolerable until they are invisible.

- Deputy Director of 'International Race Relations and Editor of European Race Bulletin' published an article titled "Cultural Cleansing?" She wrote that political and religious leadership of Europeans have been fed up from separate identity and culture of Muslims.

- Freedom Center (USA) organized an anti-Islam campaign titled 'Islamo-Fascism Awareness Week' at almost two hundred higher education institutions in USA. ${ }^{28}$

\subsection{Observations from June 2008 to April 2009}

- Institute of Race Relations (IRR) reported that Labor Party, Socialist Party and Party of Freedom had launched campaigns for removing minarets and building large mosques in the Netherlands.

\footnotetext{
May 2008)"

${ }^{27}$ Islamophobia Observatory, " $1{ }^{\text {st }}$ OIC Observatory Report on Islamophobia (May 2007 to

${ }^{28}$ Ibid.
} 


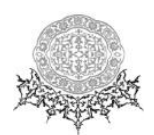

- 'Anti-Islamization Congress' was conducted by Israeli parliamentarians, where racists and neo-fascists from Spain, Italy, USA, Austria, Belgium, Hungary and UK participated to abuse Islam and Muslims in Europe.

- David Harrowitz launched his $3^{\text {rd }}$ Islamo-Fascism Week with the title of 'Stop the Jihad on Campus' in more than 100 higher educational institutions of USA.

- The West started blaming OIC for demonizing and criminalizing Christianity through observing Islamophobia in Western societies. ${ }^{29} 30$

\subsection{Observations from May 2009 to April 2010}

- People of France, UK, Switzerland, Italy, Spain and Greece protested against establishment of mosques, minarets, graves and wearing veils.

- Norwegian newspaper published caricatures of Prophet Muhammad (SAW).

- Biased books were written with Islamophobic content. ${ }^{31} 32$

\subsection{Observations from May 2010 to April 2011}

- Biased books were written with Islamophobic content. ${ }^{33}$

- Pastor named Terry Jones wanted to celebrate 'Burn a Qur'ān Day.'

- The Chairman of US House of Representative Committee on Homeland Security used very insulting and defamatory language and so-called findings about Muslims with highly premature generalizations.

- The official report of 'Council of Europe' suggested to its Parliamentary Assembly that Muslims were feeling alien, discriminated, and vulnerable in EU states.

- Tea Party Movement was launched in USA with a slogan of 'Stop Islamization of America.'

- Freedom Party of Austria added a link on a blasphemous online game titled 'Bye Bye Mosque.'

- New York Times reported that Muslims are less than two present of American population, but they have to face equal to one quarter discrimination according to

\footnotetext{
${ }^{29}$ This campaign was contributed by American Center for Law and Justice; The American Organization, The Washington Times; The European Center for Law and Justice; Canadian Free Press etc.

${ }^{30}$ Islamophobia Observatory, " 2 nd OIC Observatory Report on Islamophobia (June 2008- April 2009)," (Damascus: Organization of Islamic Conference, 2009), 1-48, http://ww1.oicoci.org/uploads/file/Islamphobia/Islamophobia_rep_May_23_25_2009.pdf

${ }^{31}$ Eurabia: The Euro-Arab Axis; The Legacy of Jihad; While Europe Slept: How Radical Islam is Destroying the West from Within; Surrender: Appeasing Islam, Sacrificing Freedom; Muslim Mafia: Inside the Secret Underworld That's Conspiring to Islamize America.

${ }^{32}$ Islamophobia Observatory, " 3 rd OIC Observatory Report on Islamophobia (Intolerance and Discrimination Aganist Muslims)," (Dushanbe: Organization of Islamic Conference, 2010), 1-70, http://ww1.oic-oci.org/uploads/file/Islamphobia/2010/en/Islamophobia_rep_May_22_5_2010.pdf.pdf

${ }^{33}$ Tyranny of Silence; and Germany Abolishes Itself.
} 


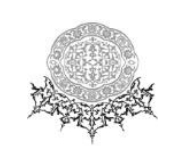

Equal Employment Opportunity Commission, annually. It mentioned that this ratio of discrimination had increased from $20 \%$ to $80 \%$ since $2005 .{ }^{34}$

\subsection{Observations from May 2011 to September 2012}

- US troops burnt Holy Qur'ān in Afghanistan.

- Terry Jones burnt Holy Qur'ān in USA.

- A blasphemous film 'The Innocence of Muslims' was uploaded at Youtube.

- English Defense League and Danish Defense League organized anti-Muslim protests and did propaganda through social media respectively.

- Anti-Muslim blogs ${ }^{35}$ were created to contribute in Islamophobia.

- Far-right political parties ${ }^{36}$ exposed their high level of Islamophobia.

- Center for American Progress exposed some anti-Muslim and anti-Islam propagandists' organizations ${ }^{37}$ and their financiers ${ }^{38}$ in America.

- Biased books were written with Islamophobic content. ${ }^{39}$

- Caricatures of Prophet Muhammad $(S A W)$ were propagated by Charlie Hebdo. ${ }^{40}$

\subsection{Observations from October 2012 to September 2013}

- Republican Party (USA) played an anti-Islamic card in its presidential election campaign (2013).

- Daniel Pipes, Robert Spencer and Pamela Geller (extreme Islamophobists) demonstrated and protested against Islam and Muslims at Washington, San Francisco and New York.

\footnotetext{
${ }^{34}$ Islamophobia Observatory, " 4 th OIC Observatory Report on Islamophobia (Intolerance and Discrimination Aganist Muslims),” (Astana: Organization of Islamic Conference, 2011), 1-70, http://ww1.oicoci.org/uploads/file/Islamphobia/2011/en/islamphobia_rep_May_2010_to_April_2011_en.pdf

${ }^{35}$ Counter Jihadists, Gates of Vienna, and Brussels Journal.

${ }^{36}$ Freedom Party (Austria), Freedom Party (Netherland), Golden Dawn (Greece), The Finns (Finland), NPD (Germany), Danish People's Party (Denmark), British National Party (UK), National Front (France), Sweden Democrats (Sweden), Vlaams Belang (Belgium), Jobbik (Hungary), and Progress Party (Norway).

${ }^{37}$ American Congress for Truth, Counterterrorism and Security Education and Research Foundation, Middle East Forum, David Horowitz Freedom Center, Investigative Project on Terrorism, Jihad Watch, Clarion Fund, and Center for Security Policy.

${ }^{38}$ Donors Capital Fund, Richard Scaife Foundations, Lynde and Harry Bradley Foundation, Russell Berrie Foundation, Anchorage Charitable Fund and William Rosenwald Family Fund, Fairbook Foundation, and Newton and Rochelle Becker foundations.

${ }^{39}$ From Muhammad to Bin Laden; Muhammad's Monsters; Militant Islam Reaches America; Onward Muslim Soldiers; Manifestations of Islamic Martyrology; Jihad and Genocide; The Truth About Mohammed: Founder of the World's Most Intolerant Religion etc.

${ }^{40}$ Islamophobia Observatory, " 5 th OIC Observatory Report on Islamophobia," (Djibouti: Organization of Islamic Cooperation, 2012), 1-92, http://ww1.oicoci.org/uploads/file/islamphobia/reports/english/islamphobia-report-2012.pdf
} 


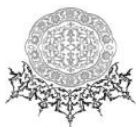

- Institute for Social Policy and Understanding published its special report on bullying of Muslim children in USA.

- Gallup reported that Americans have Islamophobia more than ever.

- 'International Religious Freedom Report' described a very bad picture of Muslims living in Europe under harsh conditions caused by Islamophobia.

- 'European Network against Racism' reported that the veil of Muslim women is under attack in Europe. ${ }^{41}$

\subsection{Observations from October 2013 to April 2014}

- OIC reported the highest ratio of Islamophobia observed ever in Central African Republic, Sri Lanka, Angola, Crimea and Myanmar.

- Quebec Charter of Values observed an exclusive legislative development at Canada.

- Ban on slaughter of halal animals was observed in some European countries.

- Issue of veil of Muslim women was again ignited in Europe.

- The Netherlands, Italy, Belgium, Switzerland and France were observed as host countries of Islamophobia.

- Previously highlighted institutions and organizations (in the report of Center for American Progress) had been observed as worst promoters of Islamophobia.

- US military and police also contributed in Islamophobia through accusing innocent Muslims, making cartoons, tattoos, and writing slogans on duty.

- Anti-Sharia bills were intentionally introduced in US Congress. ${ }^{42}$

\subsection{Observations from May 2014 to April 2015}

- A Danish Psychologist wrote a book titled 'Among Criminal Muslims: A Psychologist's Experience from the Copenhagen Municipality.' He significantly wrote that 'Islam creates monsters.'

- 'Pew Research Center' found that Americans show least warmth for Muslims than any other ethnicity in their country.

- Islamophobia was observed in ascendance in Western countries since the incident of 'Charlie Hebdo.'

- Canadians feel insecurity among Muslims since their reaction on Quebec legislative issue.

\footnotetext{
${ }^{41}$ Islamophobia Observatory, "6 6 th OIC Observatory Report on Islamophobia," (Chonakry: Organization of Islamic Cooperation, 2013), 1-90, https://www.oicoci.org/upload/islamophobia/2013/en/islamphobia_report_2013.pdf

${ }^{42}$ Islamophobia Observatory, "7 $7^{\text {th }}$ OIC Observatory Report on Islamophobia" (Jeddah: Organization of Islamic Cooperation, 2014), 1-120, https://www.oicoci.org/upload/islamophobia/2014/en/reports/islamophoba_7th_report_2014.pdf
} 


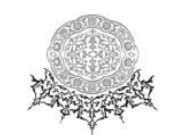

- American Republican (John Bennett) commented that he had read Qur'ān, where he had found $90 \%$ of its content as violent and only $10 \%$ can be said as peaceful.

- Head of 'Christian Anti-Defamation Commission' mentioned on its official website that ISIS had showed us the real face of Islam. So, there is no place for it in our civilized society.

- Geller, Worrisome Still and far-right anti-Muslim group planned to organize an exhibition for awarding ten thousand dollars to the winner, who will make a best cartoon of Prophet Muhammad $(S A W)$.

- A very powerful campaign was launched for anti-halal meat in Europe.

- PEGIDA [Patriotic Europeans against the Islamisation of the West (an antiIslamic movement)] was observed as working in more than a half dozen countries of Europe, which harnesses very effective, modern and legitimate tools of antiMuslim propaganda.

- Member of Party of Freedom in The Netherlands spoke at Representative Congress and objected towards Muslims in these words, as 'Dutch unity, identity and culture are being wrecked by immigration and via wombs.' 43

\subsection{Observations from May 2015 to September 2016}

- Islamophobia got a significant magnitude in Western society because of refugee crisis, discourse of Trump in his election campaign and terrorist attacks in Europe.

- Some new trends and magnitude of Islamophobia have been observed as significant in Myanmar, India, Australia and Thailand.

- 'Pew Research Center' and other reliable polling agencies have concluded that Islamophobia is not rising only in Western countries, but also in non-Western countries.

- Rise of ISIS and civil wars in Syria, Iraq and Afghanistan had contributed a lot in the rise of Islamophobia.

- Various banned and exposed propagandist organizations of anti-Islam are working with their full potential in the host communities of Islamophobia. ${ }^{44}$

\section{Reasons of Islamophobia}

There are many reasons behind Islamophobia, which vary from country to country and society to society, but there are some common points of references that are counted as reasons of Islamophobia particularly in the West. Firstly, Muslims and Islam are narrowly considered as static and unresponsive to social change. Secondly, Islam is known as a monolithic religion, which negates the fundamental

\footnotetext{
${ }^{43}$ Islamophobia Observatory, " 8 th OIC Observatory Report on Islamophobia," 1-71.

${ }^{44}$ Islamophobia Observatory, "9 ${ }^{\text {th }}$ OIC Observatory Report on Islamophobia," (Tashkent: Organization of Islamic Cooperation, 2016), 1-134, https://www.oicoci.org/upload/islamophobia/2016/9th_islamophobia_annual_report_en.pdf
} 


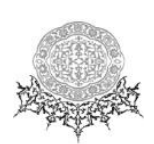

authenticity of religious texts of other religions. Thirdly, the West shows a strong hesitation in considering Islam as a progressive religion. It (West) considers Islam as an outdated and inferior religion on earth. Fourthly, it considers Islam as the strongest opponent of science among other religions in the world. Fifthly, Islamophobia is a manifestation of a population to exclude Muslims and Islam from their host society.

According to observations of Islamophobia Observatory, the following reasons of Islamophobia having been observed as significant,

- Lack of knowledge and understanding about Islam is the prime reason behind Islamophobia. Therefore, the popular propaganda wins that Islam rose through sword, which further preaches hate to non-believers and stands to challenge the modern and Western way of life.

- Misrepresentation of Muslim societies and their contemporary state of victimization in the American War on Terror and rising level of extremism is contributing to Islamophobia.

- Exploitation of the right of freedom of expression is also contributing to the phenomenon, when mass media in non-Muslim world (particularly in West) does not discriminate between terrorists and victims of terrorism in Muslim world. Therefore, powerful propaganda of this mind set is contributing to Islamophobia.

- Inciting behavior of some individuals, groups, organizations and other entities to promote ethnic violence is significantly contributing in the rise of the target phenomenon.

- Insufficient legal binding is one of the factors to restrict the Islamophobia-based literature and hate speech is an element of Islamophobia.

- Lack of political will of stakeholders particularly of host communities of Islamophobia for organizing a serious dialogue upon nodes of conflicts and terms of agreement are contributing in Islamophobia.

- Phenomenon of cheap labor is one of the significant factors of Islamophobia in the West, where local citizens face unemployment in their home countries. ${ }^{45}$

Thus, OIC has narrated the attitude of the host populations of Islamophobia as irresponsible, offensive, suspicious, and predisposed fear of Muslims and Islam. ${ }^{46}$

\section{Practical Examples of Mitigation of Islamophobia}

OIC frequently conducts conferences, consortiums, seminars, workshops and inter-religious dialogues for creating awareness in people about Islamophobia and

\footnotetext{
${ }^{45}$ Islamophobia Observatory, " $1{ }^{\text {st }}$ OIC Observatory Report on Islamophobia (May 2007 to May 2008)," 1-56.

46" Islamophobia: Looking at the Causes," Edited by Dr. Isam Salim Shanti. The Journal.(2006) Accessed April 10, 2016. http://www.oic-oci.org/english/article/islamophobia.htm.
} 


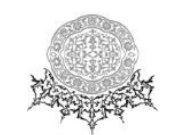

realization to mitigate it effectively. Its target population of address mostly consists of leadership and representatives of inter-governmental originations, states and government officials, civil society, media, educational elite and various stakeholders including those from host population of Islamophobia. The following information has been organized to highlight some high profile developments to mitigate Islamophobia, as those were mentioned in the annual reports of Islamophobia Observatory since 2008-2016.

\subsection{Observations from May 2007 to May 2008}

- OIC convinced UN and EU to condemn the nefarious exercise of Danish citizens to produce caricature of Prophet Muhammad $(S A W)$.

- EU High Representative for 'Common Foreign and Security Policy' (CFSP) met with Secretary General of OIC to take up the issue at UN for more international consensus and commitment to avoid defamation of Islamic religion. Later on, Secretary General of 'Council of Europe' also condemned that act of violence and offense upon the faith of a community.

- Mayor of Brussels city stopped the rally titled 'Stop the Islamization of Europe.' Later, Secretary General of Council of Europe also condemned the rally.

- Government of the Netherlands stopped the campaign of far-right opposition party for banning Holy Qur'ān in the country.

- Italian Interior Minister opposed the campaign of banning veil of Muslim women at public places.

- 'European Commission against Racism and Intolerance' (ECRI) issued general policy guidelines and recommendations to prevent minorities from discrimination and defamation.

- Director of 'Yale Center for Faith and Culture' and 300 people from Christian scholarship (including clergy) gather at Abu Dhabi and wrote a letter to their counterparts for collective apology of sins and crimes of Christians done either in Crusade wars or in contemporary wars (including in American War on Terror) against Muslim community.

- OIC directorate presented its concerns over celebration of 'Islamo-Fascism Awareness Week' in USA. It raised the issue at $62^{\text {nd }}$ UN General Assembly to neutralize the target campaign.

- OIC has sponsored a number of resolutions to introduce legislation against Islamophobia and defamation of religion. These legislations not only had been passed by UN Human Rights Council, but also had been introduced in some countries too. ${ }^{47}$

\footnotetext{
${ }^{47}$ Islamophobia Observatory, " $1{ }^{\text {st }}$ OIC Observatory Report on Islamophobia (May 2007 to
} May 2008)," 1-56. 
7.2. Observations from June 2008 to April 2009

- 'Durban World Review Conference' held upon racism, discrimination, xenophobia and other kinds of issues relating to intolerance in 2009. Its outcome document recognized the phenomenon of Islamophobia. OIC convinced it to do more efforts to mitigate it effectively.

- Campaigns of banning Holy Qur'ān, release of film Fitna and making caricatures of Prophet Muhammad $(S A W)$ were banned through government at some EU countries.

- Council of Europe passed a resolution (no. 1605) in its Parliamentary Assembly (2008) as a warning for Islamophobia activists. It recognized that Islam is the second major religion and an integral component of European society. It issued ethical guidelines to mitigate Islamophobia from Europe. Moreover, it issued a White Paper titled 'Living together as Equal in Dignity' for promotion of intercultural dialogue in Europe. ${ }^{48}$

\subsection{Observations from May 2009 to April 2010}

- British Foreign Secretary delivered his speech at Oxford University and demonstrated a great deal of respect for Muslims and Islam.

- Government of Ireland passed an anti-defamation bill to set a punishment of 25000 Euros fine for violation of the target Bill.

- New York City Council Education Committee decided to add holidays of religious festivals of Muslims in their school calendar.

- Representatives of OIC member states strongly condemned the Swiss ban on minarets of mosques in Switzerland. ${ }^{49}$

\subsection{Observations from May 2010 to April 2011}

- Secretary General of OIC submitted his concerns over burning of Holy Qur'ān Day in USA. Then, political, administrative and military elite of USA did efforts to stop the act and condemned it frequently.

- 'Council of Europe' passed a resolution (no. 1743) titled 'Islam, Islamism, Islamophobia in Europe,' in its Parliamentary Assembly and introduced strict regulations of this issue.

- UK launched 'All Party Parliamentary Group' on Islamophobia at its 'House of Commons' for tightening the actors of Islamophobia.

\footnotetext{
${ }^{48}$ Islamophobia Observatory, "2 ${ }^{\text {nd }}$ OIC Observatory Report on Islamophobia (June 2008April 2009)," (Damascus: Organization of Islamic Conference, 2009), 1-48, http://ww1.oicoci.org/uploads/file/Islamphobia/Islamophobia_rep_May_23_25_2009.pdf

${ }^{49}$ Islamophobia Observatory, "3 ${ }^{\text {rd }}$ OIC Observatory Report on Islamophobia (Intolerance and Discrimination Aganist Muslims)" (Dushanbe: Organization of Islamic Conference, 2010), 1-70, http://ww1.oic-oci.org/uploads/file/Islamphobia/2010/en/Islamophobia_rep_May_22_5_2010.pdf.
} 


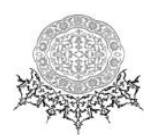

- Ministers of Foreign Affairs of OIC member states passed a declaration for countering Islamophobia through a comprehensive and institutional approach. ${ }^{50}$

7.5. Observations from May 2011 to September 2012

- Danish High Court heavily fined the president of 'Free Press Society' for passing insulting remarks about Muslims.

- Freedom Party of Austria' had to face incitement charges by local authorities upon posting a blasphemous game online.

- Local authorities of Germany announced for surveillance and scrutiny of antiMuslim websites in the country.

- Deputy Premier of Australia called on members of 'Parliament of Katter's Australian Party' and 'Liberal National Party' for promotion of Islamophobia.

- OIC took initiative of launching 'Istanbul Process' to mitigate religious intolerance. $^{51}$

7.6. Observations from October 2012 to September 2013

- US Congress organized a hearing upon the state of Islamophobia at US.

- 'Council of Europe,' UNESCO, and 'Organization for Security and Cooperation in Europe' (OSCE), recognized the recent wave and threat of Islamophobia to Muslims in host societies.

- 'Toronto Board of Rabbis,' banned Pamela Geller by recognizing her an extreme Islamophobist. $^{52}$

\subsection{Observations from October 2013 to April 2014}

- A French journalist had to face prosecution because of abusing Islam.

- UK punished a mosque attacker with a prison sentence of 22 months.

- US Court ordered Google to remove a blasphemous film 'The Innocence of Muslims' from Youtube.

- German President was observed as praising Islamic ideology.

- The mayor of New York City announced public holidays at religious festivals of Muslims.

${ }^{50}$ Islamophobia Observatory, “4 ${ }^{\text {th }}$ OIC Observatory Report on Islamophobia (Intolerance and Discrimination Aganist Muslims)," 1-70, http://ww1.oic-

oci.org/uploads/file/Islamphobia/2011/en/islamphobia_rep_May_2010_to_April_2011_en.pdf

${ }^{51}$ Islamophobia Observatory, " 5 th OIC Observatory Report on Islamophobia (Djibouti: Organization of Islamic Cooperation, 2012)," 1-92, http://ww1.oicoci.org/uploads/file/islamphobia/reports/english/islamphobia-report-2012.pdf

${ }^{52}$ Islamophobia Observatory, " 6 th OIC Observatory Report on Islamophobia," (Chonakry: Organization of Islamic Cooperation, 2013), 1-90, https://www.oicoci.org/upload/islamophobia/2013/en/islamphobia_report_2013.pdf 
- Canadian police department and FIFA allowed Muslim women to wear a standardized veil.

- OIC officials met with Pope Francis and convinced him to work for common cause of religion. ${ }^{53}$

\subsection{Observations from May 2014 to April 2015}

- UK Government punished its citizens with fine for tearing up the pages of Holy Qur'ān.

- Sri Lankan court imprisoned and fined extremist Buddhist monks on insulting the Holy Qur'ān.

- Prime Minister of Australia addressed Muslim population and ensured them that no one can make them second class citizens in Australia. He also made sure that Muslim women should be confident upon wearing veil in the country.

- The mayor of New York City stopped an anti-Muslim campaign of abusing Muslims through painting blasphemous content on city buses.

- German President criticized anti-Islamic campaigns in his Christmas message to German nation.

- The president of France warned anti-Muslim protestors and activists of severe consequences.

- Saudi-Arabia tightened its rules about blasphemous content of Dutch businessmen.

- Host communities of Islamophobia started anti-PEGIDA campaigns in Europe.

- Governments of Australia, UK, Canada, US, Sweden and Greece allowed Muslims to build mosques in their countries.

- Governments of Australia, UK, and US allowed Muslim women to wear veil in their countries.

- Governments of US, Germany, and France supported and took initiatives for interfaith and intercultural dialogues in their countries. ${ }^{54}$

\subsection{Observations from May 2015 to September 2016}

- OIC shared the report and its findings with those institutions which are working on the same issue and also with those stakeholders where Islamophobia exists with a very high magnitude.

- Competition of exhibiting the caricatures of Prophet Muhammad (SAW) was banned by local authorities in some parts of America.

- A pastor of UK was imprisoned over anti-Islamic sermon.

- Anti-Islamists had to face prosecutions over Islamophobia. A number of them were imprisoned and were made to pay heavy fines.

${ }^{53}$ Islamophobia Observatory, " 7 th $O I C$ Observatory Report on Islamophobia," 1-120.

${ }^{54}$ Islamophobia Observatory, " 8 th $O I C$ Observatory Report on Islamophobia," 1-71. 


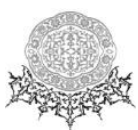

- Prime Minister of Canada praised Muslims and Islam and criticized Islamophobia.

- Local unbiased activists have started counter Islamophobia campaigns at personal, group and organizational levels in host societies of Islamophobia.

- Muslims also have started to practice their legal rights through approaching judiciary, law enforcement agencies and engaging their local well-wishers in host societies of Islamophobia. ${ }^{55}$

\section{International Declarations and Commitments Towards Islamophobia}

OIC has precedence in this regard that it highlighted the phenomenon of Islamophobia timely and passed a numbers of resolutions and declarations from its forums for commitment, awareness, and countering it effectively. ${ }^{56}$ At the same time, it has worked with other intergovernmental organizations and various stakeholders to address it in their own constituencies in host regions of Islamophobia.

- OIC took initiative and issued (2006) a trilateral joint statement (secretary generals of OIC, UN and EU High Representative for Common Foreign and Security Policy) against blasphemous acts of making cartoons of Prophet Muhammad $(S A W)$.

- OIC issued (2006) a joint statement regarding right of peaceful protest and freedom of expression with secretary generals of OIC, Arab League, UN and with the high profile representatives from Turkey, Qatar, Spain.

- OIC convinced the UN to make Islamophobia part of its special report of UN Human Rights Council on Contemporary Forms of Racism, Radical Discrimination and Xenophobia in 2007. This was a significant development, when UN defined the phenomenon of Islamophobia first time in its history.

- Final drafts of declaration and resolutions possessed commitments of participating member countries of OIC at its $11^{\text {th }}$ OIC Islamic Summit to address Islamophobia.

\footnotetext{
${ }^{55}$ Islamophobia Observatory, "9 9 th OIC Observatory Report on Islamophobia," (Tashkent: Organization of Islamic Cooperation, 2016), 1-134, https://www.oicoci.org/upload/islamophobia/2016/9th_islamophobia_annual_report_en.pdf

${ }^{56}$ Conference on Islamophobia; Historical Reconciliation; At Home in Europe? Muslims in EU Cities (UK); Role of Media in the Development of Tolerance and Mutual Understanding; Dialogue of Civilizations (Azerbaijan); Islamophobia and the Challenge of Pluralism in the $21^{\text {st }}$ Century; Role of the Media in the West-Islam Relations; Islam-West Relations; Fostering Interfaith and Intercultural Dialogue; Global Challenges: Role of OIC at New York (USA); The High-Level Dialogue on Inter-religious and Intercultural Understanding and Cooperation for Peace (UN); Countering Discrimination and Intolerance towards Muslims and Defamation of Islam (Pakistan); Tolerance and Non-Discrimination; Freedom of Expression; 2nd Symposium on Muslim Minorities and Communities in Central and Eastern Europe: Reality and Perspectives (Russia); Fifth Asia-Europe Interfaith Dialogue (Korea); Media Misrepresentation of Islam and Muslims: The Search for Remedies (Brussels); Intercultural Dialogue: Culture of Peace-Avenue of Multiculturalism (Istanbul); Doha Meeting for Advancing Religious Freedom through Interfaith Collaboration (Qatar) etc.
} 
- OIC introduced, sponsored and did efforts to pass a resolution (no. 60/150) at UN General Assembly titled 'Combating Defamation of Religion.' 57

- Council of Europe passed a resolution (no. 1605) in its Parliamentary Assembly (2008) as a warning for Islamophobia activists. Moreover, it issued a White Paper titled 'Living together as Equal in Dignity' for promotion of intercultural dialogue in Europe. ${ }^{58}$

- UN High Commissioner visited OIC head quarter and endorsed the concerns of Secretory General of OIC to address the issue through intergovernmental organizations. ${ }^{59}$

- Council of Europe passed a resolution (no. 1743) titled 'Islam, Islamism, Islamophobia in Europe,' in its Parliamentary Assembly and introduced strict regulations of this issue.

- UK launched an 'All Party Parliamentary Group on Islamophobia' at its House of Commons for tightening the actors of Islamophobia.

- Ministers of Foreign Affairs of OIC member states passed a declaration for countering Islamophobia through a comprehensive and institutional approach. ${ }^{60}$

- Local authorities of Germany announced for surveillance and scrutiny of antiMuslim websites in the country.

- OIC took initiative of launching 'Istanbul Process' to mitigate religious intolerance. $^{61}$

- A large number of Western countries have allowed Muslims for building mosques and wearing veils. ${ }^{62}$

\section{Conclusion}

This target independent and limited study concludes that OIC has successfully built a legitimate and collective response of Muslim world and of international community towards Islamophobia through establishing an Islamophobia Observatory and sharing its findings with other stakeholders in the world. It took a right decision to tackle some of the challenges of this social evil through an inclusive and participatory approach. Therefore, Islamophobia Observatory has built a capacity to guide and provide an evidence of this menace in its host communities particularly in the West. Its target estimations of Islamophobia

\footnotetext{
${ }^{57}$ Islamophobia Observatory, " $1{ }^{\text {st }}$ OIC Observatory Report on Islamophobia (May 2007 to May 2008)," 1-56.

58“"2nd OIC Observatory Report on Islamophobia (June 2008- April 2009)," 1-48.

59“'UN High Commissioner for Human Rights vist OIC," OIC Journal (Organization of Islamic Conference), no. 13, (2010): 38.

60 “ $44^{\text {th }}$ OIC Observatory Report on Islamophobia (Intolerance and Discrimination Aganist Muslims)," 1-70.

61 " $5^{\text {th }}$ OIC Observatory Report on Islamophobia," 1-92.

62 " $8^{\text {th }}$ OIC Observatory Report on Islamophobia," 1-71.
} 


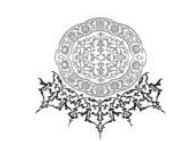

had convinced international community to realize this issue as a violation of basic human rights of Muslims.

The rising trends of Islamophobia show that European governments and to some extent their media, educational institutions, civil society and intellectual scholarship are either not capable to tackle the phenomenon or they are intentionally hesitant to counter it on a massive scale, as its magnitude have been observed as increasing rather than decreasing. Hence, comprehensive and sincere efforts (declarations and commitments) of the international community are being awaited for implementation in the host communities of Islamophobia.

\section{Way Forward}

In host regions of Islamophobia following steps are suggested to be taken:

- Members and representatives of Muslim community should realize their primary concerns about Islamophobia and consult with the relevant people, institutions and public bodies in Islamophobic societies to address their matters through public administration, legislation and policy making process rather than just individual response.

- Members of Muslim community (both collectively and individually) should file their concerns into court of law and at other effective forums to probe, convict and reduce the momentum of Islamophobia,

- Host countries of Islamophobia should adopt national plans of actions for eradicating Islamophobic preaches, particularly regulating the media groups and organizations,

- Publication and dissemination of any kind of Islamophobic content should be realized as separate from freedom of expression. So, its offenders must be detained as violating of basic human rights.

- Muslims should present the real message and picture of Islam, which is being defamed and distorted since many decades.

- Regional study centers (Middle Eastern, European, Oriental etc.), institutes and think thanks including NGOs should promote harmony, cohesion and inclusiveness in their literature and schools of thought to magnify and signify the cleavages and fault-lines on ethnic basis, which ultimately lead to ethnic violence, hate and violations of basic human rights since Islamophobia is one manifestations of this phenomenon.

- Global institutions for justice, peace and reconciliation should be functional and play their impartial role to solve international security crises in Middle East, North Africa, South Asia, Eastern Europe, Caucasia and other frozen conflicts in the world such as Indian occupied Jammu and Kashmir and Palestine, Afghanistan, Iraq, Syria etc. which cause Islamophobia and perpetual conflict in the world. 


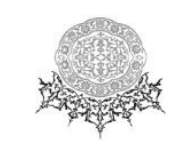

- Constant and instant state of dialogue and debate is inevitable to refine the basic issues of understanding between Muslim and Western societies.

\section{Bibliography}

Anis, Ahmed. "Editorial: Future of Islamophobia." Edited by Prof. Dr. Anis Ahmed. Maghrib aur Islam (West and Islam): Fear of Islam in the West (IPS Press: Institute of Policy Studies) 18 no. 43 (2): (2015): 5-13.

Awad, Nihad. "Anti-Muslim Bias on the Rise in the US." OIC Journal. no. 5, 2007.

Elbusefi, Mohamed. "Tackling Blasphamous E-Content against Islam." OIC Journal (Organization of Islamic Conference). no. 12, (2009)

Ihsanoğlu, Prof. Ekmeledin. " $6^{\text {th }}$ Islamic Conference of Culture Ministers Adopts Action Plan for Joint Islamic Cultural Action." OIC Journal (Organization of Islamic Conference). no. 12, (2009): 1-90, https://www.oicoci.org/upload/islamophobia/2013/en/islamphobia_report_2013.pdf

-. "Lisbon Forum 2009: OIC Secratory General Stresses on Need to Catalyze Intercivilizational and Interfaith Dialogue." OIC Journal (Organization of Islamic Conference). no. 12, 2009.

-. "Speech of His Excellency Prof. Ekmeledin Ihsanoğlu Secratory General of the Organization of the Islamic Conference." 2006. Accessed April 16, 2016 <http://www.oic-oci.org/baku2006/english/sg-speech.htm>.

-. "Stop Jazum Minarett-Verbot." OIC Journal (Organization of Islamic Conference). no. 12, (2009)

Islamophobi Observatory. " $5^{\text {th }}$ OIC Observatory Report on Islamophobia." Djibouti: Organization of Islamic Cooperation (2012): 1-92, http://ww1.oicoci.org/uploads/file/islamphobia/reports/english/islamphobia-report-2012.pdf

-. "1 ${ }^{\text {st }}$ OIC Observatory Report on Islamophobia (May 2007 to May 2008)." Kampala: Organization of Islamic Conference (2008): 1-56, http://ww1.oicoci.org/uploads/file/Islamphobia/islamphobia_rep_may_07_08.pdf

-. "2nd OIC Observatory Report on Islamophobia (June 2008- April 2009)." Damascus: Organization of Islamic Conference (2009): 1-48,http://ww1.oicoci.org/uploads/file/Islamphobia/Islamophobia_rep_May_23_25_2009.pdf

-. " $3{ }^{\text {rd }}$ OIC Observatory Report on Islamophobia (Intolerance and Discrimination Aganist Muslims)." Dushanbe: Organization of Islamic Conference (2010): $1-70$, http://ww1.oicoci.org/uploads/file/Islamphobia/2010/en/Islamophobia_rep_May_22_5_201 0.pdf.pdf

- . " $4^{\text {th }}$ OIC Observatory Report on Islamophobia (Intolerance and Discrimination Aganist Muslims).” Astana: Organization of Islamic Conference (2011): 170, http://ww1.oic- 


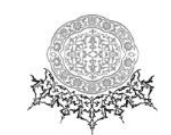

oci.org/uploads/file/Islamphobia/2011/en/islamphobia_rep_May_2010_to_A pril_2011_en.pdf

-. " $6^{\text {th }}$ OIC Observatory Report on Islamophobia." Chonakry: Organization of Islamic Cooperation (2013): 1-90, https://www.oicoci.org/upload/islamophobia/2013/en/islamphobia_report_2013.pdf

-. " $7^{\text {th }}$ OIC Observatory Report on Islamophobia." Jeddah: Organization of Islamic Cooperation (2014): 1-120, https://www.oicoci.org/upload/islamophobia/2014/en/reports/islamophoba_7th_report_2014. pdf

—. " 8 th OIC Observatory Report on Islamophobia." Kuwait: Organization of Islamic Cooperation (2015): 1-71, https://www.oicoci.org/upload/islamophobia/2015/en/reports/8th_Ob_Rep_Islamophobia_Fin al.pdf

- " "9 $9^{\text {th }}$ OIC Observatory Report on Islamophobia." Tashkent: Organization of Islamic Cooperation (2016): 1-134, https://www.oicoci.org/upload/islamophobia/2016/9th_islamophobia_annual_report_en.pdf

Organization of Islamic Cooperation. "UN High Commissioner for Human Rights visit OIC.” OIC Journal (Organization of Islamic Conference), no. 13(2010): 38.

Organization of Islamic Cooperation. "History of Organization of Islamic Cooperation." Accessed March 12, 2016 <http://www.oicoci.org/oicv3/page/?p_id=52\&p_ref=26\&lan=en>.

Organization of Islamic Cooperation. "Islamophobia: Looking at the Causes and Ways to tackle Them.” Edited by Dr. Isam Salim Shanti. OIC Journal. 2006. Accessed April 10, 2016, <http://www.oicoci.org/english/article/islamophobia.htm>.

Orhun, Ambassador (R) Ömür. "Muslims in the West." OIC Journal (Organization of Islamic Conference). no. 12, (2009): 46-47.

Ronald M., Ada P. Kahn. and Christine Adamec. The Encyclopedia of Phobias, Fears, and Anxieties. 3rd. New York: Facts on File, 2008.

Shanti, Dr. Isam Salim. "Dushanbe Meeting: Realities and Changes." OIC Journal (Organization of Islamic Conference). 13, no. (6): 2010.

Taib, Ambassador Saadeddin. "What Does the OIC Stand for?" The Journal (Organization of Islamic Conference) no. 5, 2007. 